\title{
Marine Biodiversity Threats and Conservation
}

\author{
Thavasimuthu Citarasu* \\ Manonmaniam Sundaranar University Rajakkamangalam, India \\ * Correspondance author: Thavasimuthu Citarasu, Centre for Marine Science and Technology, Manonmaniam Sundaranar University \\ Rajakkamangalam, Kanyakumari District, Tamilnadu, India
}

Submission: 制 February 06, 2018; Published: 踻 February 26, 2018

\section{Opinion}

Marine ecosystem is mainly threatened by natural and artificial factors by human interruption. Natural factors such as storms, waves including cyclones, natural radiations, volcanic lava, tsunami and freshwater runoff are affect directly or indirectly the marine biodiversity. The natural factors can change the ocean temperature or $\mathrm{pH}$ that leads to changes of nutrient availability, biological productivity, reproductive success, the timing of biological processes (e.g., spawning), biogeography, migrations, community structure, predator-prey relationships, and entire biomes. Altered patterns of wind and water circulation in the ocean environment will influence the vertical movement of ocean waters (i.e., upwelling and down welling). Warming of both air and ocean temperatures has resulted in the loss of Arctic sea ice that affects the marine mammals such as ice seals and polar bears. The oceans are normally a natural carbon sink, absorbing carbon dioxide from the atmosphere, the levels of atmospheric carbon dioxide are increasing, and the oceans are becoming more acidic.

The acidity interfere affecting corals and the ability of shellfish to form shells. By human activity, excessive harvests of fish and shellfish (including their by catch) will not only reduce the population size of fisheries resources but also change the species composition of their preys and predators, and even balance in the whole food web. Over cutting of mangrove plants affect the marine animals' reproduction. Illegal or over-exploitation of marine animals for medicines/ oil extraction will seriously affect the normal biodiversity. Coral beds may affect by ship anchoring, excessive harvest for cement factories and ornamental aquarium beautifications. Various pollutants released by human activities seriously affected the marine biodiversity nowadays. The hydrocarbon compounds like alkenes, naphthalenes, benzenes, xylene and polycyclic aromatic hydrocarbons from the oil spills are highly toxic to phyto and zooplanktons, small fishes and birds. Heavy metals like mercury, lead, copper, nickel and cadmium from industries and anti-fouling paints seriously affect the marine animals by inducing various malformations. Water released from nuclear reactors, thermal power stations create oxygen depletions, the altered or low level oxygen change the degradation level and create suffocation affect the primary productivity and migration of animals to other places. High temperature causes, release of immature eggs or can prevent normal development, increase metabolic rate, enzyme activity and consume more food leading to disturb the food chain. Excess input of nutrients and hydrogen sulfide inputs from fresh water bodies affect the productivity leading to disturb the food chain. Noise pollutions including passing ships, oil exploration seismic surveys, and naval low-frequency active sonar interrupt the communications of marine mammals leading to mass death. Ship based threatening by operational and accidental pollution discharges sewages, tank residues, bunker oils, garbage and ballast water affects the normal biodiversity. Removing parts of the seafloor for ocean mining disturbs the habitat of benthic organisms. Discarded plastic bags, six pack rings and other plastic waste are dangers to fisheries and causes death to seabirds and turtles. Micro plastics discharged from cosmetics and detergents affect the reproduction of fishes. Coastal tourism and fishing activity also causes serious problems to the marine animals by different ways.

Several measures are need to protecting/conserving the marine biodiversity from the natural and human interruption. Illegal and over exploitation of capture fisheries and other animals for medicinal or other purposes should be stopped. For illegal catching Fishermans and fishing vessels to advised to follow the fisheries law and act. Fishing of protective/endangered species should be strictly banned. Sea ranching and induced breeding technology, the populations of endangered species may be increased. Illegal cutting of mangrove forests and poaching of endangered species must be stopped. In order to stop or minimize various pollutants caused by human activities, almost the biodiversity may be saved. Government must educate the marine and environment related laws to the public and student community for aware the pathetic effects of marine biodiversity impacts and destruction. Public must strictly follow the coastal and marine activity laws including Indian fisheries act 1987, Indian port act 1902, Merchant shipping act 1974, Wildlife protection act 1972, Water act 1974 (prevention and control of pollution), Marine zones of India act 1987 and Environment protection act 1987 and National Marine sanctuaries Act of 1972, Fisheries Management and Conservation Act-1976,Clean Water Act of 1977, Endangered Species Act, Oceans Act of 2000, Estuaries and Clean Waters Act of 2000 and Estuaries and Clean Waters Act of 2000 etc. By strictly following the Environmental act 1986. 
a) We have treated the sewage or industrial effluents by bioremediation process for minimize /stop the discharge of pollutants to the entry of sea.

b) Stop dumping the fly ash from thermal station and other solid waste dumping.

c) Land reclamation; boundary or disturbing the natural course of sea water.

d) Altering of sand dunes and other natural features including landscape changes.

Education is also a very important and powerful criterion to address the pollution problems, especially for school students and create awareness. Because school students and youngsters take their responsibility and awareness to the public peoples, families and related communities related to the marine pollutions and the future conservations etc. Coastal cleanup is the major awareness programme; the International Coastal Cleanup is one of the largest volunteer programs in world for cleaning the coastal areas. Volunteers are clean or remove trash from the coastal areas especially beaches the entire world. Waste management is also an important strategy for restrict the entry of pollutants through effluents to the clean water bodies. Industries are advised to set up waste proper treatment plants, minimize waste for adopting suitable measures, waste recycling and reuse and recovery of waste water effluents.
Your subsequent submission with Crimson Publishers will attain the below benefits

- High-level peer review and editorial services

- Freely accessible online immediately upon publication

- Authors retain the copyright to their work

- Licensing it under a Creative Commons license

- Visibility through different online platforms

- Global attainment for your research

- Article availability in different formats (Pdf, E-pub, Full Text)

- Endless customer service

- Reasonable Membership services

- Reprints availability upon request

- One step article tracking system 